\title{
Conflict and Climate: Drivers of Fire Activity in Syria in the Twenty-First Century
}

\author{
Maria Zubkova, ${ }^{\mathrm{a}}$ Louis Giglio, ${ }^{\mathrm{a}}$ Michael L. Humber, ${ }^{\mathrm{a}}$ JoAnne V. Hall, ${ }^{\mathrm{a}}$ And Evan EllicotT ${ }^{\mathrm{a}}$ \\ ${ }^{a}$ Department of Geographical Sciences, University of Maryland, College Park, College Park, Maryland
}

(Manuscript received 10 April 2021, in final form 25 May 2021)

\begin{abstract}
It has been 10 years since the start of the Syrian uprisings. While relative stability is improving overall, a new disaster, wildfires, impacted an already food-insecure population by burning through key production areas, damaging crops, soil, and livestock and causing air quality to deteriorate. As observed with remotely sensed data, fire affected $4.8 \%$ of Syria in 2019 , as compared with the average $0.2 \%$, and most fires were observed within agricultural land in the northeast. Abnormal amounts of rainfall during the 2019 growing season and, consequently, high soil moisture explained about $62 \%$ of the drastic increase in the burned area extent. In contrast, in 2020, fires continued despite the average amount of rainfall. Extremely high temperature could partially explain a 10-fold increase in the extent of burned area in 2020 but only within forested regions in the northwest. We argue that the abrupt changes in Syria's fire activity were driven by the complex interactions among conflict, migration, land use, and climate. On one side, the ongoing conflict leads to a drastic increase in the number of accidental and deliberate fires and reduced capacity for fire response. On the other side, years of insecurity, widespread displacement, and economic instability left no choice for locals other than exploiting fires to remove natural vegetation for expanding farming, logging, and charcoal trading. The loss of agricultural production and natural vegetation to fire can have serious implications for food security, soil property, biodiversity, and ecosystem services, which can further exacerbate the already unstable economy and make ongoing violence even more intense.
\end{abstract}

KEYWORDS: Wildfires; Forest fires; Land use

\section{Introduction}

The Syrian civil war (2011-present) has received much attention not only from the media but also from the science community. Scholars are still debating about the original cause of Syria's civil war: the direct impact of climate change that led to a significant drought between 2006 and 2009 (Kelley et al. 2015) or the socioeconomic and governmental policies, political awakening among the population, and Syrian president alAssad's repression of dissent (Selby et al. 2017; Mohammed et al. 2020a). However, the impacts of the civil war on humans, biodiversity, and ecosystem services are not up for debate. By early 2020, 586100 lives were lost, approximately 6.2 million Syrians were displaced, and 9.3 million Syrians faced food insecurity (United Nations Security Council 2020). The Syrian agricultural sector, in particular, suffered significant losses (Mohammed et al. 2020a). While years of droughts undoubtedly had an adverse effect on agriculture, additional stressors such as widespread population displacement, damaged infrastructure, crop looting, and crop burning severely exacerbated food supply shortages (Mohammed et al. 2020a; Linke and Ruether 2021). The agricultural sector's role as one of the main sectors of the Syrian economy (Tothova et al. 2019) makes it a valuable asset (Selby et al. 2017; Linke and Ruether 2021). All sides of the Syrian conflict have strategically targeted cropland

Corresponding author: Maria Zubkova,mzubkova@umd.edu

Earth Interactions is published jointly by the American Meteorological Society, the American Geophysical Union, and the Association of American Geographers. not only as a main source of income but for control over civilians and to support rebel fighting (Koren and Bagozzi 2017; Enab Baladi 2019; Linke and Ruether 2021). As a result of the arid climate, Syrian ecosystems are very susceptible to fire, making it a cheap and easy tool for removing not only natural vegetation but also cultivated land and agricultural production.

After the cease-fires beginning in 2016, conflict intensity started to decline. By the end of 2018, the Syrian army reclaimed control over the main large cities, and by mid-2020 the Syrian government forces were in control of approximately two-thirds of the country (Group on Earth Observations Global Agricultural Monitoring 2021). However, while relative stability improved overall, the conflict moved to the north, closer to the border with Turkey and Iraq (BBC 2019a), where 62\% of the cultivated land is located (Mohamed et al. 2020). Consequently, the presence of active conflict in close proximity to agricultural lands impaired farmers' access to fields and increased the number of maliciously started fires (Group on Earth Observations Global Agricultural Monitoring 2021). An adverse effect of the remaining conflict on cropland production was supported by the World Food Programme (WFP 2021), which documents the increasing number of people with food insecurities every year.

Because of limited data gathering in unsafe conflict zones, reliable estimates of the burned area extent in Syria are lacking. The use of remotely sensed data can be highly beneficial in estimating changes within conflict zones (Eklund et al. 2017). A recent study by Schon et al. (2021) that was based on satellite active fire detections from the Aqua and Terra Moderate Resolution Imaging Spectroradiometer (MODIS) reported unusually high fire activity in 2019 in Syria, which they attributed to the increase in agricultural productivity and therefore 
concluded that "fire in Syria is more likely to be linked with stabilization." However, according to the FAO (2020), the number of food-insecure people increased by 1.4 million between 2019 and 2020, and the beginning of 2021 was the period with the worst food security situation ever seen in Syria (WFP 2021).

In general, changes in fire activity are caused by either natural or anthropogenic drivers or a combination of both (Bowman et al. 2011; Barbero et al. 2015; Archibald 2016; Abatzoglou et al. 2018; Zubkova et al. 2019). Vegetation, ignition sources, and climate determine fire activity at a regional scale (Parisien and Moritz 2009), whereas humans can alter natural fire activity by changing its seasonality, size, and intensity (Syphard et al. 2007; Bowman et al. 2011; Daniau et al. 2012; Archibald 2016). Anthropogenic drivers of fire activity include population growth, land management, and socioeconomic factors (Pausas 2004; Marlon et al. 2008; Parks et al. 2016; Balch et al. 2017). While much attention has been drawn to land transformation and increasing population density as primary drivers of current fire activity, the role of socioeconomic changes is less studied. Indirectly, socioeconomic changes affect fire activity by either increasing or reducing the amount of anthropogenic pressure. In biomass-scarce ecosystems, increasing industrialization was found to have a potential to induce fire activity by promoting large, hot fires in areas where biomass gradually built up due to land abandonment (Moreira et al. 2001; Pausas and Fernández-Muñoz 2012; Martínez-Fernández et al. 2013; Viedma et al. 2015). On the other hand, in more biomassrich ecosystems where humans are the main ignition source, armed conflicts can reduce fire activity if the population is forcibly displaced (Gorsevski et al. 2012) or increase humaninduced fires if, during the conflict, fire management activities ceased (Gorsevski et al. 2013). However, research into how armed conflicts directly influence fire activity is rare.

In this study, we analyzed MODIS burned area (BA) to provide unbiased information on the extent of the region affected by fire in Syria during the 19-yr period 2002-20, which encompasses the period before and during the civil war. Specifically, interannual variability in fire activity was analyzed together with conflict intensity, land use, and climate. In addition, we systematically explored a simple relationship between BA and climate before and during the civil war, considering several climate metrics that proved to be strong predictors of fire activity in the arid and Mediterranean climate. The overarching goal of this study was to investigate the drivers behind unusually high fire activity in 2019 and 2020 to improve our understanding of the causal mechanisms that drive fire in the context of conflict and extreme weather variability.

\section{Study area}

\section{a. Climate and vegetation}

The Syrian Arab Republic (herein, Syria) is located in the northern part of the Arabian plate, between latitudes $32^{\circ}$ and $38^{\circ} \mathrm{N}$ and between longitudes $35^{\circ}$ and $43^{\circ} \mathrm{E}$. According to the Köppen climate classification, the climate in Syria varies between the Mediterranean on the west and arid on the southeast (Rubel and Kottek 2010). Consequently, the annual rainfall ranges substantially from $100 \mathrm{~mm}$ in the south to $1000 \mathrm{~mm}$ in the west. Most of the annual rainfall (90\%) occurs in the winter (October-April), whereas during summer the precipitation drops to less than $1 \mathrm{~mm}$ per month (June-August). Temperature is the highest during July and August $\left(29^{\circ} \mathrm{C}\right.$ on average) and drops to $7^{\circ} \mathrm{C}$ in January, with the temperature gradient changing from west to east.

Major vegetation types follow climate gradient. A small amount of forest can be found only in the Mediterranean part of the country, the south desert part of Syria has very low vegetation represented by grassland and cropland, and the north part of the country is dominated by croplands (Fig. 1) according to Land Cover Climate Change Initiative (LC-CCI; ESA 2017). Most agricultural fields in Syria are cultivated with three main crops: wheat predominantly in the northeast part of the country, the most important strategic crop in Syria; cotton on the east, first of Syrian agricultural exports; and olive trees in the west, making Syria the sixth largest country in olive production in the world (Mohammed et al. 2020a).

\section{b. Geopolitics and conflict}

Syria is administratively subdivided into 14 governorates, with the capital city Damascus located in the southwest part of the country. Other than the capital, the most populated areas in Syria are located along the Mediterranean coast. As of 2020, the population of Syria was estimated at 17501000 , which is 18\% less than in 2010 according to the United Nations (2019). The population density started to decline in 2011, reaching its minimum in 2018 (16945000; United Nations 2019). This drastic decline in population density was caused by violence during the country's civil war (2011-ongoing), including displaced people, deaths, and missing persons (Syrian Observatory for Human Rights 2020).

Protests and uprisings started in the densely populated southwest part of Syria in March 2011 that escalated quickly to a full-fledged civil war between the Syrian government and the various antigovernment rebel groups (Encyclopaedia Britannica Online 2020). The conflict's three main campaigns were identified as coalition efforts to defeat the Islamic State, violence between the Syrian government and opposition, and military operations against Syrian Kurds by Turkish forces (Council on Foreign Relations 2021). During the first two years of the war, the Syrian government lost political and territorial control of substantial areas. In 2013, the Islamic State began to expand its territory, and by late 2014, agricultural regions in the north of Syria had become the Islamic State stronghold (Hassan and Nordland 2018). By the middle of 2015, the Islamic State was in control of one-third of Syria's cropland and $15 \%$ of the cropland in Iraq (Eklund et al. 2017). At least 30\% of the Islamic State revenues were coming from selling agricultural products and taxing farmers (Almukhtar 2016). This triggered direct intervention from the U.S. military, which was followed by Russian military interventions in 2015 and 2016 (Yacoubian 2021).

By 2016, the Islamic State was beginning to collapse after being targeted by Kurdish forces and their American allies, pro-Assad Syrian forces supported by Iran and Russia, and a Turkish-backed coalition of rebel groups (Encyclopaedia Britannica Online 2020). The Syrian government started to regain its power, and a cease-fire agreement was reached by the 

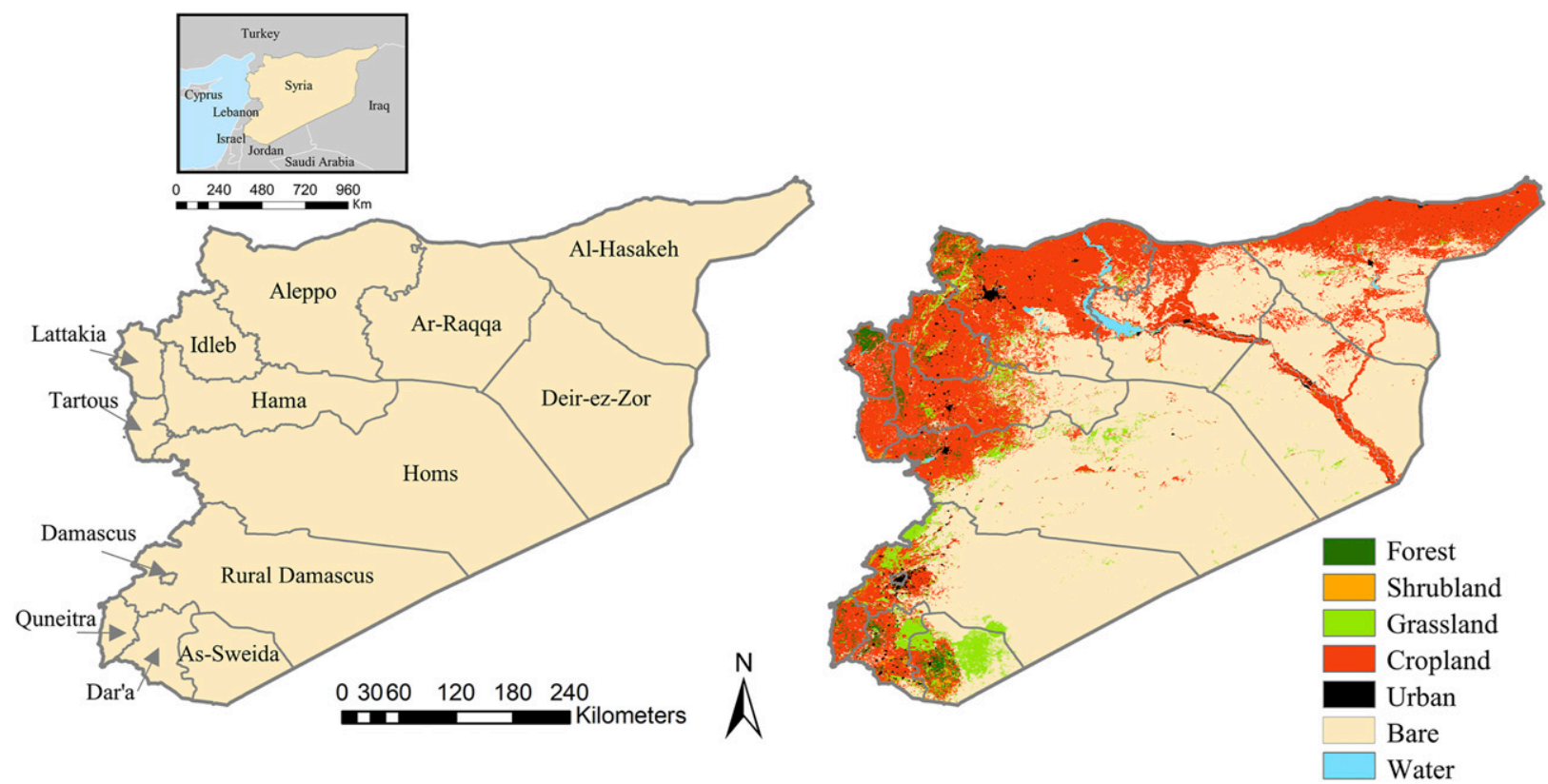

FIG. 1. Study area. Location of the study area showing (left) the 14 governorates of Syria and (right) the main land-cover types.

United States and Russia in 2016 (Walker and Shaheen 2016). By 2018, Kurdish forces significantly reduced the remaining territory of the Islamic State (BBC 2019a), specifically suburbs surrounding Damascus and most of the southwest part of Syria (Yacoubian 2021). Despite various cease-fires that reduce the intensity of the war, violent conflict events are still occurring in the northeast, the "breadbasket of the country," and northwest, the richest natural reserves (Strand et al. 2019; Amnesty International 2020; Action on Armed Violence 2020a).

The remaining conflict continues to have a profound effect on the Syrian population. Just in 2019 alone, more than 7000 people were killed in Syria (Strand et al. 2019). Between May 2019 and February 2020, Amnesty International (2020) documented 18 attacks on medical facilities and schools in the northwest. On 6 October 2020, at least 19 civilians were killed in a car bomb explosion in the north (Action on Armed Violence 2020a), forcing more people to abandon their homes and seek refuge. The overall financial damage in the agricultural sector during the first 6 years of the war was equivalent to about one-third of Syria's GDP in 2016 (Group on Earth Observations Global Agricultural Monitoring 2021). The loss from the fires in 2019 in Ar Raqqah alone has been valued at USD 9 million (Asharq Al-Awsat 2019). In addition, many civilians were injured or killed in the fires, being left alone to protect their land in the absence of fire response services (Assistance Coordination Unit 2019). In October 2020, over 70 people in northwest Syria were hospitalized with respiratory illnesses (WFP 2020a). The loss of agricultural production as a result of fire will have serious implications for food security and will further exacerbate the already unstable economy and make ongoing violence even more intense (Linke and Ruether 2021).

\section{Methods}

\section{a. Preliminary analysis: Conflict events}

To determine time intervals for evaluating fire activity with regard to the political situation in Syria, conflict events were analyzed using data from the Integrated Crisis Early Warning System (ICEWS 2016) and the Armed Conflict Location and Event Data Project (ACLED; Raleigh et al. 2010). While ICEWS provides data for the entire study period (2002-20), its data source is limited to news articles and online sources. In contrast, ACLED data are available only from 2017 onward but are derived from a number of secondary information sources, including primarily press accounts from local and regional news sources, Integrated Regional Information Network (IRIN), ReliefWeb, Factiva, and humanitarian agencies (Raleigh et al. 2010). All nonviolent events were excluded from the analysis.

\section{b. Statistics for burned area}

The extent of the BA within Syria's border and within each of the 14 governorates was estimated from the 500-m-resolution MODIS Collection-6 MCD64A1 global burned area product (Giglio et al. 2018) between 2002 and 2020. The BA estimates were summarized using several time intervals to reflect conditions before and during the civil war, as well as the individual calendar year and individual months within the fire season (FS). The FS was defined as the minimum number of consecutive months in which $80 \%$ of the total average annual BA occurs (Abatzoglou et al. 2018). The BA was also estimated specifically within cropland since cropland fires during the growing season can have serious economic and environmental consequences. The cropland mask was calculated using 
the LC-CCI v.1.6.1 Annual Global Land Cover at 300-m resolution (ESA 2017).

A $Z$ score was used to evaluate the difference between average conditions (2002-18) and fire activity during an individual year; $Z$ is a measure of the number of standard deviations $\sigma$ that a raw score $x$ lies below or above the population mean $\mu$ (Kreyszig 1979); that is,

$$
Z=(x-\mu) / \sigma
$$

We chose 2002-18 to represent the average condition since the years 2019 and 2020 have been documented as outliers experiencing abnormally high fire activity in Syria (FAO 2019; WFP 2020a; Schon et al. 2021).

\section{c. Climate analysis}

Several climatic variables and temporal aggregation windows were tested to identify relevant features. Using existing literature, we chose three temporal windows to account for weather conditions prior to and during the FS: 1) growing season (GS) from October to April, based on the FAO crop calendar for wheat and barley (the main cultivated crops in Syria), to represent antecedent conditions that drive biomass accumulation (Krawchuk and Moritz 2011) [here we used the GS to account for antecedent conditions based on the finding of Schon et al. (2021)]; 2) FS to represent concurrent conditions that drive fuel desiccation (Littell et al. 2009); and 3) each month within the FS ( $\left.\mathrm{FS}_{\text {monthly }}\right)$ to describe fire weather.

As was mentioned earlier, Syria has a strong moisture gradient; therefore, we hypothesized that one climate metric would not be sufficient to characterize different processes limiting fire within the context of the multivariate environment (Bradstock 2010). Consequently, we expected that in arid, water-limited parts of the country, where fuel is the main limitation of fire, the amount of moisture available for plants would be the main climate predictor of BA since it drives fuel accumulation (Higgins et al. 2000; Bird et al. 2012; Daniau et al. 2012). Moisture availability in this analysis was represented by precipitation $P(\mathrm{~mm})$ and soil moisture content at $0-10-\mathrm{cm}$ depth (SM; \%), which showed to be a stronger predictor of BA in arid regions than was $P$ (Zubkova et al. 2019). Precipitation and SM within the GS were calculated from the Famine Early Warning Systems Network Land Data Assimilation System (FLDAS) that uses Climate Hazards Group Infrared Precipitation with Station Data (CHIRPS) and MERRA-2 as inputs for precipitation and temperature (McNally et al. 2017).

As one moves west, the amount of precipitation increases; hence, those areas can support much higher biomass production. While fuel availability is less tightly coupled to short-term variations in moisture (Bradstock 2010), severe ambient weather conditions, such as extremely high temperature, low humidity, and strong wind, are needed to reduce atmospheric moisture and fuel moisture to create favorable conditions for fire ignition and propagation (Flannigan et al. 2009; Daniau et al. 2012). Therefore, we also included air temperature $T$ at $2 \mathrm{~m}$ above the land surface $\left({ }^{\circ} \mathrm{C}\right)$ and the Canadian fire weather index (FWI) acquired from the ERA5-the ECMWF atmospheric global reanalysis (Hersbach et al. 2020; Vitolo et al.
2020). FWI is based on daily surface weather variables, including temperature, relative humidity, precipitation, and wind speed, that quantify the potential of fire to ignite and spread, resulting in damage and other impacts (Wotton 2009; Abatzoglou and Kolden 2013; Bedia et al. 2018). First, we calculated daily maximum $T$ and FWI based on hourly ECMWF data, and then we aggregated it within each month and FS, calculating average and maximum.

The climate analysis consisted of two parts. First, the interannual and seasonal correlations of climate and BA were analyzed by calculating Spearman's rank-order coefficient between the base-10 logarithm of BA and climate variables using the 2002-18 period. Later, based on the results of correlation analysis, we chose climate variables that showed the strongest relationship with BA to fit a simple linear model:

$$
\log \mathrm{B} \mathrm{A}=\beta_{0}+\beta_{1} \mathrm{C} 1+\varepsilon,
$$

where $\mathrm{C} 1$ represents antecedent (GS) or concurrent (FS and $\mathrm{FS}_{\text {monthly }}$ ) climate condition and $\varepsilon$ represents an error term. The model was fitted using data during the $2002-18$ period and was subsequently used to predict BA in 2019 and 2020, the two years with extremely high fire activity, to estimate how much of the increase in the observed BA can be attributed to climate.

\section{d. Neighboring countries}

Last, we analyze changes in fire activity in two neighboring countries, Iraq and Turkey, that share the border with governorates in Syria that experienced the highest fire activity. While we expect to see similar interannual variability in climate, the variation of BA between neighboring countries can be attributed to the differences in agricultural practices, land management, governmental policies, and economy.

\section{Results}

\section{a. Preliminary analysis: Conflict events}

Temporal changes in the number of violent conflicts are summarized in Figs. 2 and 3 . According to ICEWS, the number of conflicts was close to the minimum before the beginning of the civil war, after which it drastically increased, peaking in 2012 and remained high until 2019 with a reduction of conflict intensity after the cease-fire decision in 2016. However, the number and temporal changes of conflict events varied between ICEWS and ACLED datasets. Overall, ACLED recorded 31130 violent conflicts in 2017, 20303 in 2018, 19310 in 2019 , and 11613 in 2020, whereas those numbers were much lower according to ICEWS (6169, 6966, 3249, and 990, respectively). Based on ACLED, while conflicts remained prevalent in the northwest (Idlib, Hama, and Aleppo), patterns of conflicts in the northeast changed. Specifically, in $\mathrm{Al}$ Hasakah and Ar Raqqah, the number of conflicts more than doubled between 2018 and 2019 and continued to increase in 2020. Conflict intensity raised in Al Hasakah from 575 in 2018 to 1207 in 2019 and 1495 in 2020 and in Ar Raqqah from 293 to 587 and 1076. In particular, the "battles" conflict type in $\mathrm{Al}$ Hasakah increased by 3.4 times in 2019 and 2.6 times in 2020 and in Ar Raqqah by 5.2 and 5.9 times relative to 2018 


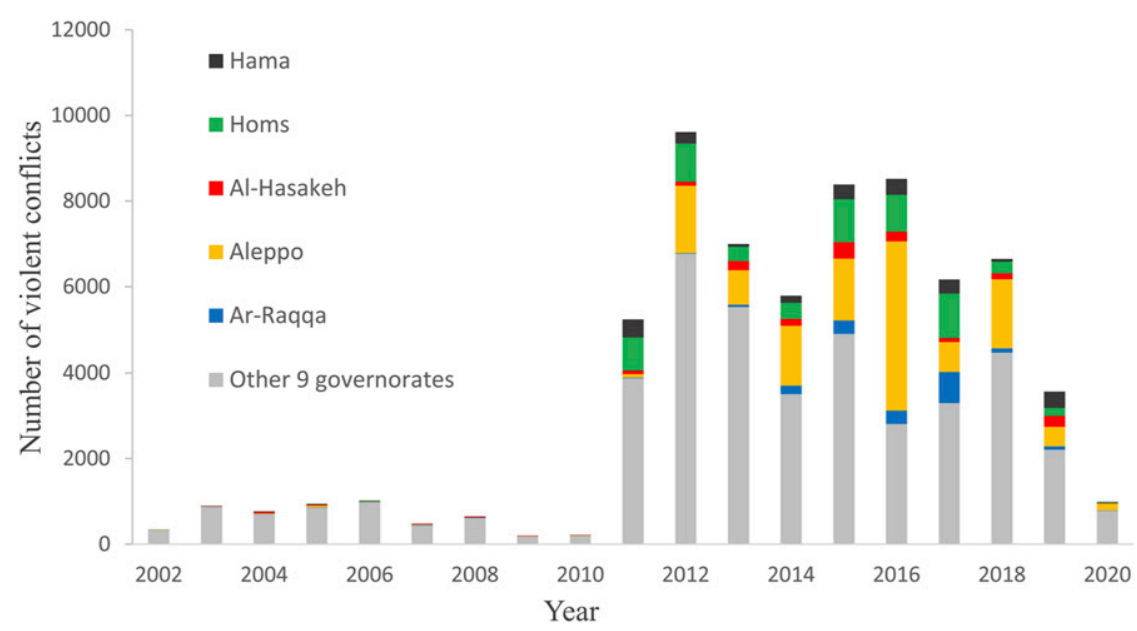

FIG. 2. Time series of conflict events based on ICEWS data (2002-20). All nonviolent events were excluded from the analysis.

statistics. The "violence against civilians" conflict type increased by 1.7 and 2.2 in Al Hasakah and 1.6 and 3.6 times in Ar Raqqah, respectively. The location of the conflicts also changed, shifting closer to the border with Turkey, where most of the agricultural fields were located (Fig. 3). These changes in location were further demonstrated when conflicts were analyzed together with land cover. The number of violent conflicts within cropland drastically increased between 2017 and 2019.
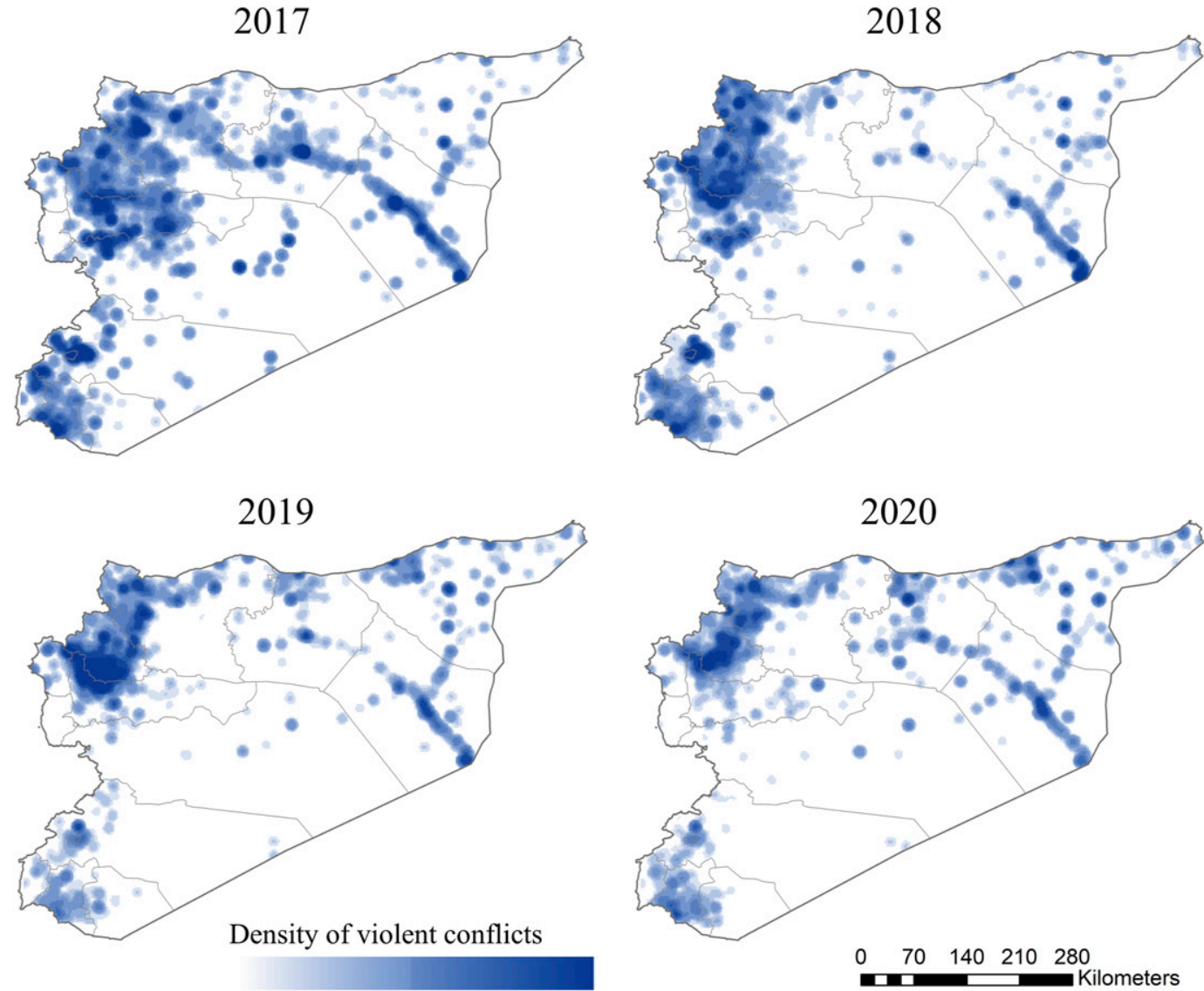

$<100 \quad 500 \quad 2500 \quad 8000 \quad>20000$

FIG. 3. Density of violent conflicts based on ACLED data. "Protests" and "nonviolent event" types of events were excluded. 
TABLE 1. Summary of fire activity in Syria and its governorates (Damascus was not included because of negligible fire activity). Time intervals represent the period before the civil war (2002-10), the civil war before the cease-fire (2011-15), the period after the cease-fire (2016-18), the average over 2002-18, 2019 separately as a year with the most abnormal fire activity, and 2020 as the most recent full year.

\begin{tabular}{|c|c|c|c|c|c|c|}
\hline \multirow[b]{2}{*}{ Governorates } & \multicolumn{6}{|c|}{ Avg burned area $\left(\mathrm{km}^{2}\right)$} \\
\hline & $2002-10$ & $2011-15$ & 2016-18 & $2002-18$ & 2019 & 2020 \\
\hline Aleppo & 69.0 & 184.7 & 24.7 & 95.2 & 1178.7 & 264.2 \\
\hline Al Hasakah & 142.9 & 150.7 & 58.5 & 130.3 & 4506.7 & 1918.4 \\
\hline Ar Raqqah & 33.8 & 26.2 & 2.1 & 26.0 & 1128.2 & 72.1 \\
\hline As Suwaydā & 0.2 & 1.1 & 0.9 & 0.6 & 1.3 & 9.0 \\
\hline Dar'a & 0.0 & 3.3 & 2.7 & 1.5 & 0.9 & 0.0 \\
\hline Dayr az Zawr & 15.4 & 15.2 & 28.0 & 17.5 & 211.7 & 0.2 \\
\hline Hama & 1.0 & 86.9 & 94.3 & 42.7 & 841.7 & 414.5 \\
\hline Homs & 14.3 & 61.2 & 13.5 & 28.0 & 694.6 & 234.2 \\
\hline Idlib & 1.5 & 14.8 & 2.2 & 5.5 & 330.6 & 255.2 \\
\hline Latakia & 9.0 & 51.6 & 9.0 & 21.5 & 5.4 & 274.8 \\
\hline Al Qunaytirah & 22.3 & 9.7 & 6.4 & 15.8 & 17.4 & 15.9 \\
\hline Rural Damascus & 2.9 & 2.4 & 10.3 & 4.1 & 19.5 & 35.4 \\
\hline Tartūs & 0.0 & 0.3 & 0.6 & 0.2 & 0.0 & 48.3 \\
\hline Total & 312.3 & 608.2 & 253.4 & 388.9 & 8936.6 & 3542.3 \\
\hline
\end{tabular}

Based on ACLED, 29.6\% of all violent conflicts in 2017 were located within cropland; this number increased to $36.3 \%$ in 2018 , reached $50.6 \%$ in 2019 , and then decreased to $44.8 \%$ in 2020 .

\section{b. Statistics on burned area}

Based on MODIS MCD64A1, between 2002 and 2018, on average, $0.2 \%$ of Syria was affected by fire, or $388.9 \mathrm{~km}^{2}$ per year (Table 1). The southern regions of Syria are mostly desert and hardly ever experience fire activity, while the majority of the BA was observed in the west and north part of the country (Fig. 4), specifically in five governorates: Aleppo, Al Hasakah, Ar Raqqah, Hama, and Homs, which together contribute to $80 \%$ of the average total BA (2002-18), $90 \%$ in 2019, and $82 \%$ in 2020 .

The following results were summarized using several time intervals: before the beginning of the civil war (2002-10), the civil war before the cease-fire (2011-15), and after the ceasefire, which was split into three periods-2016-18, 2019, and 2020 - because of the abnormally high fire activity in 2019. During 2002-10, fire affected $312.3 \mathrm{~km}^{2}$ on average, mostly in the northern part of the country with the lowest fire activity in $2008(Z=-1.1)$. During the civil war and before the cease-fire (2011-15), fire activity almost doubled $\left(608.2 \mathrm{~km}^{2}\right)$ and BA not only increased in the north of Syria but also in governorates that were usually fire free, such as Hama and Latakia. The year 2015 was the year with the highest BA between 2002 and 2018; $1485.6 \mathrm{~km}^{2}(Z=3.2)$ was affected by the fire. After the ceasefire in 2016 , BA drastically reduced to $253.4 \mathrm{~km}^{2}$ on average, mostly driven by the very low fire activity in the north part of the country. Overall, during the 2016-18 period, BA in Aleppo was $74 \%$ lower than the average (2002-18), in Al Hasakah it was $55 \%$ lower, and in Ar Raqqah it was $92 \%$ lower.

In contrast, one year later, in 2019 , fire affected $4.8 \%$ of Syria $\left(8936.6 \mathrm{~km}^{2}\right)$, resulting in an astonishing $2300 \%$ increase relative to the average fire activity $(Z=26)$. (Here and after, the term "average" refers to the average over the 17-yr period spanning 2002-18.) A year later, in 2020, while fire activity was reduced relative to 2019 , it was still 10 times the average $\left(3542.3 \mathrm{~km}^{2}\right)$. In other words, in 2019, 1.4 times more BA was detected in Syria than during the previous 17 years combined, and in $2020 \mathrm{BA}$ was equal to one-half of all of the BA that was detected between 2002 and 2018. While most governorates experienced a drastic increase in fire activity in 2019, the magnitude of this increase varied geographically, being lower within governorates on the south and substantially higher in two governorates on the northeast. BA in 2019 in Al Hasakah was $35 \sigma$ above the mean, while in Ar Raqqah, BA was $51 \sigma$ above the mean (Fig. 5), making it a $4300 \%$ increase relative to the average. A drastic increase in BA in 2020 was mostly attributed to high fire activity in Al Hasakah and the west part of Syria, specifically Idlib, Latakia, and Tartūs, which did not experience fire activity before the civil war.

Looking at the intra-annual variability of BA, it was clear that fire activity had a pronounced seasonality; the FS lasted between May and September with a peak in June with slight variations between governorates and higher variation between years (Fig. 6). For example, before the civil war, $11 \%$ of the annual BA was detected in May, whereas, between 2011 and $2018,27 \%$ of annual BA occurred at the beginning of the FS. In 2019, the peak of the FS shifted toward September, which contributed $22 \%$ of the annual BA, whereas, before 2019, BA in September contributed to only $6 \%$. This seasonal change in fire activity was mostly attributed to a drastic increase in BA in September in Al Hasakah, where $15.5 \%$ of the total BA in Syria was observed in September 2019, as compared with the usual $2 \%$. In 2020, fire activity peaked in July, and unusually high fire activity was detected not only in September but also in October. In October 2020, 40 times as much BA was detected as during the average October, which was mostly contributed by Al Hasakah, Latakia, and Tartūs.

According to the LC-CCI product, cropland was the dominant land-cover type in three of the five governorates of interest [Aleppo (67\%), Al Hasakah (51\%), and Hama (51\%)], while in Ar Raqqah cropland covered $26 \%$ and it covered only 
Cumulative fire activity prior the civil war (2002-2010)

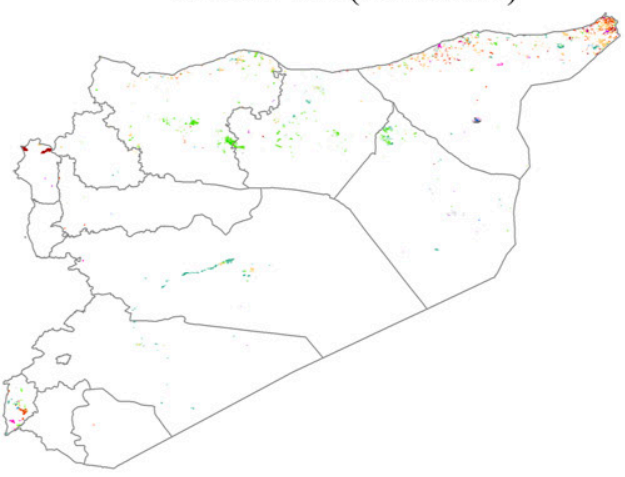

Cumulative fire activity after the cease-fire decision (2016-2018)

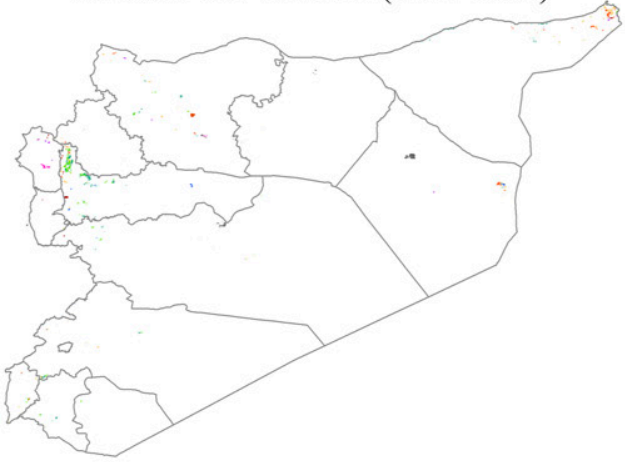

Fire activity in 2019

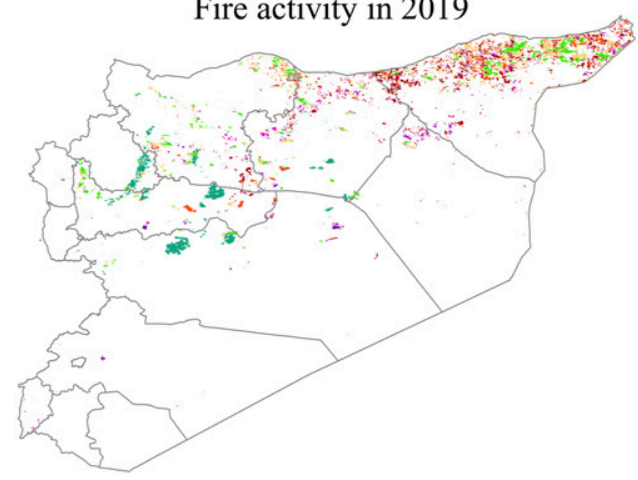

Cumulative fire activity before the cease-fire decision (2011-2015)

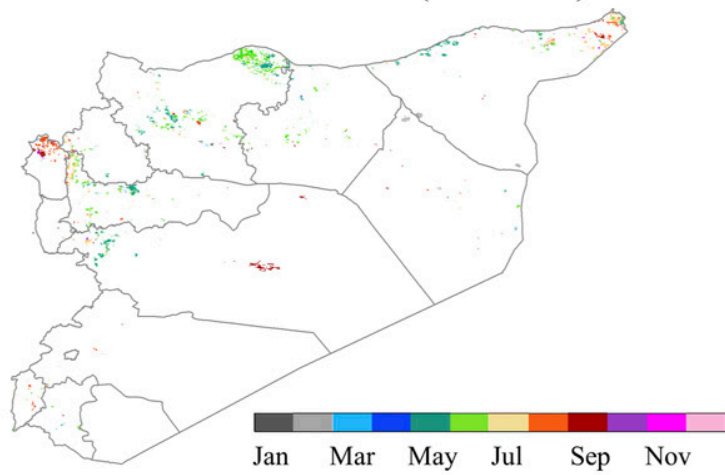

Cumulative fire activity

(2002-2018)

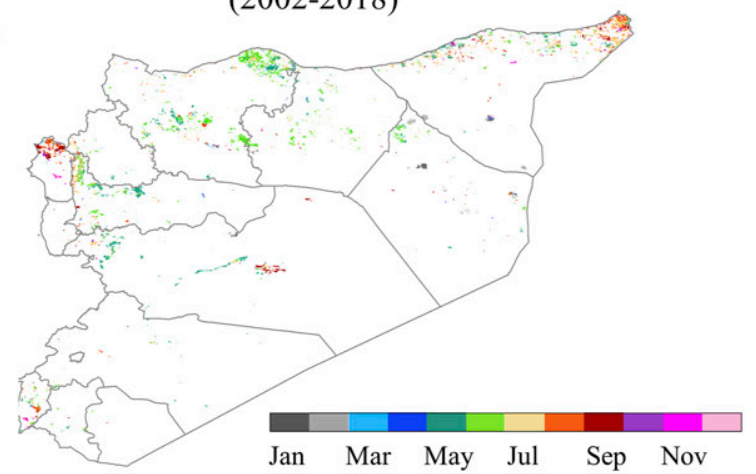

Fire activity in 2020

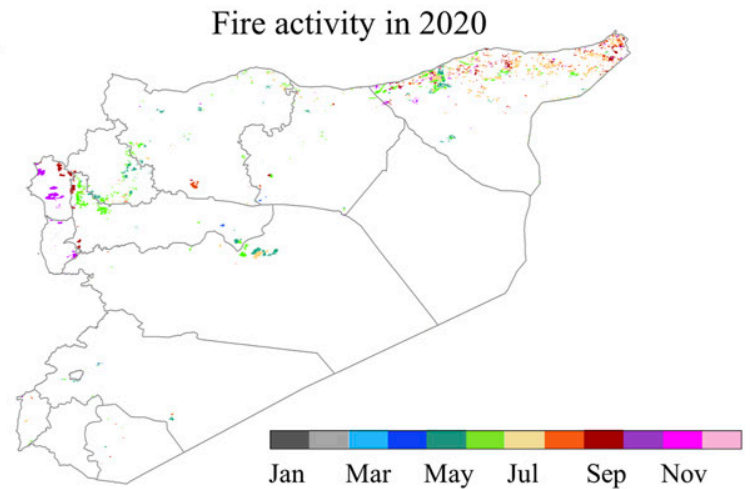

FIG. 4. Spatial distribution of burned area in Syria based on MODIS MCD64A1.

9\% in Homs. Cropland was also the main land-cover type affected by fire: on average, $81.7 \%$ of BA is within cropland. However, between years this number varied, with the highest occurring before the civil war $(84.4 \%)$, decreasing to $80.4 \%$ in $2011-15,76.9 \%$ in $2016-18$, and being the lowest in 2019 (68.1\%) and then increasing back in 2020 (79.7\%). In 2019, within cropland, BA increased by 19 times for all of Syria. Specifically, in Idlib, cropland burning increased by 66 times, in Al Hasakah by 31 times, in Homs and Ar Raqqah by 17 times, in Hama by 11 times, and 9.5 times in Aleppo. The increase was even more drastic within noncropland. MCD64A1 detected 40 times as much BA within forest, nonforest, and bare land-cover classes in 2019 relative to the average. In 2020 the increase was less dramatic but still substantial; 9 times as much BA was detected within cropland and 10 times within natural land. The amount of cropland BA increased the most in Idlib (a factor of 52), Al Hasakah (a factor of 14), and Hama (a factor of 9).

\section{c. Climate analysis}

Of the several climate variables that were considered in this analysis, BA showed the strongest relationship with accumulated SM and $P$ during the GS (October-April; $r=0.65$ and 

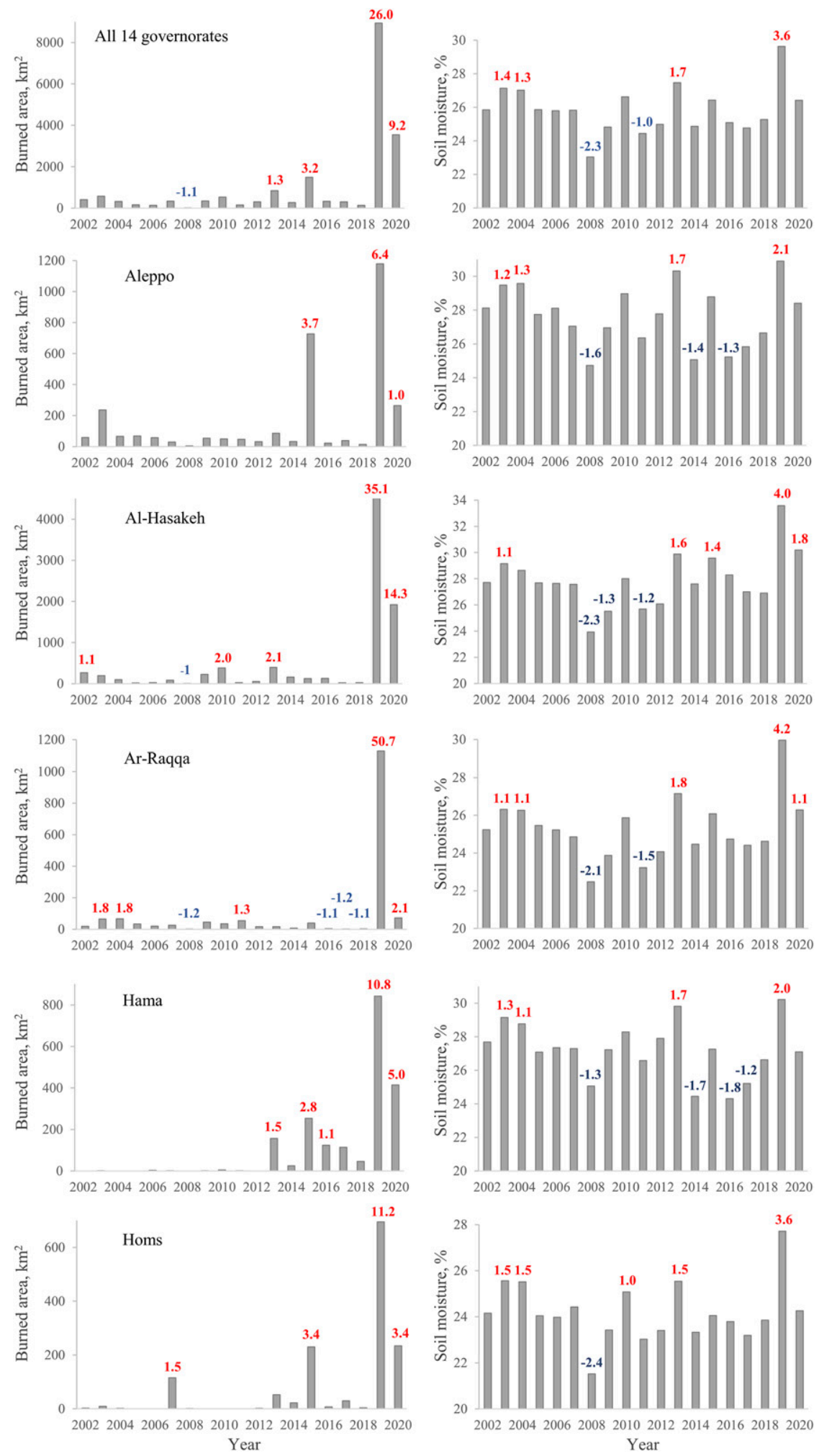

FIG. 5. Time series (2002-20) of (left) annual burned area accumulated over a calendar year and (right) average soil moisture over the growing period (October-April) in Syria and five governorates with the highest fire activity. The $Z$ score is reported only for years for which $-1 \leq Z$ (blue) or $Z \geq 1$ (red); $Z$ score was calculated using average conditions during 2002-18. 

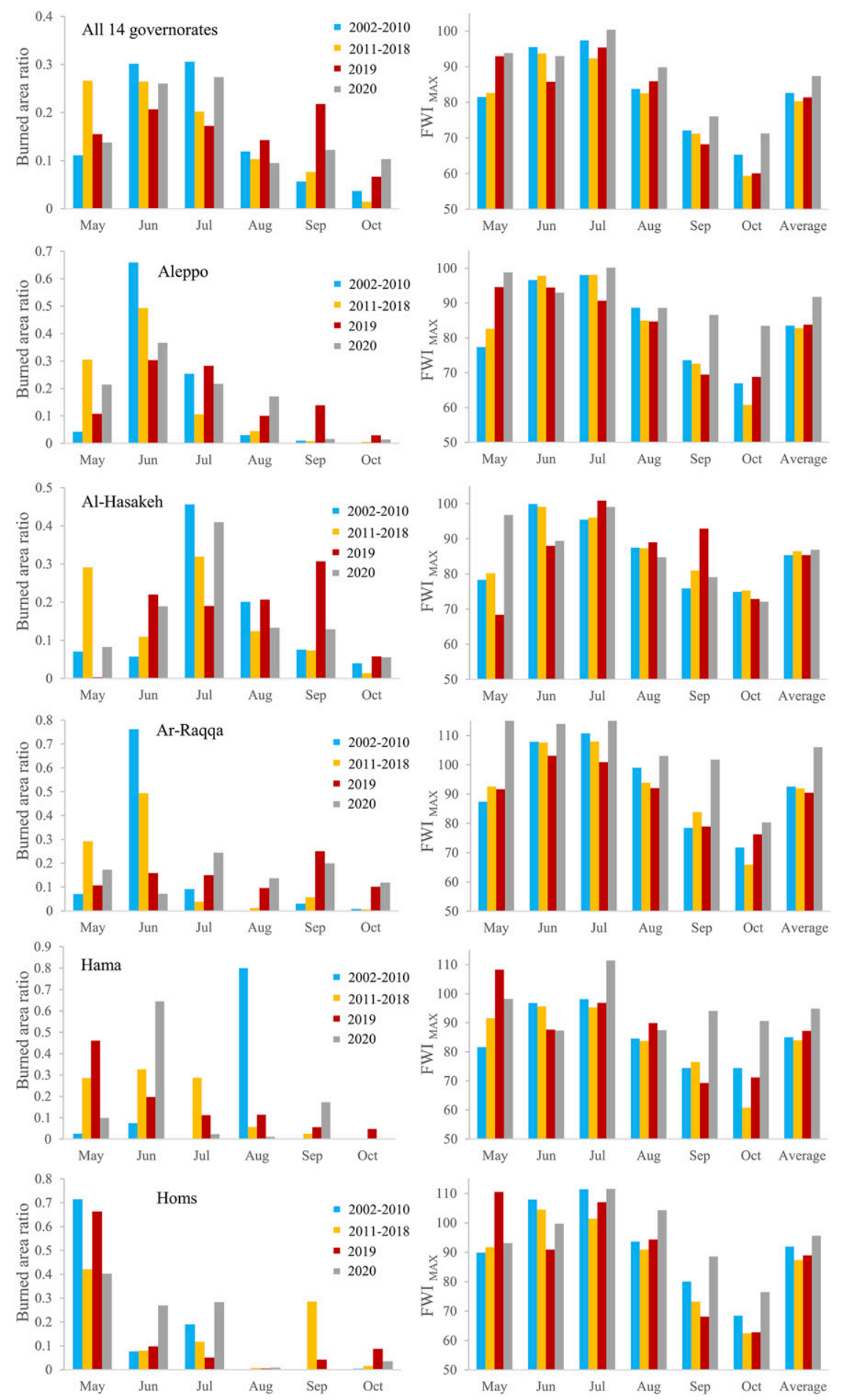

FIG. 6. Monthly climatologies (May-October) of (left) normalized burned area (monthly BA/annual BA) and (right) maximum FWI, in Syria and five governorates with the highest fire activity during four time periods: before the civil war (2002-10; blue), during the civil war (2011-18; yellow), during 2019 (red), and during 2020 (gray). 

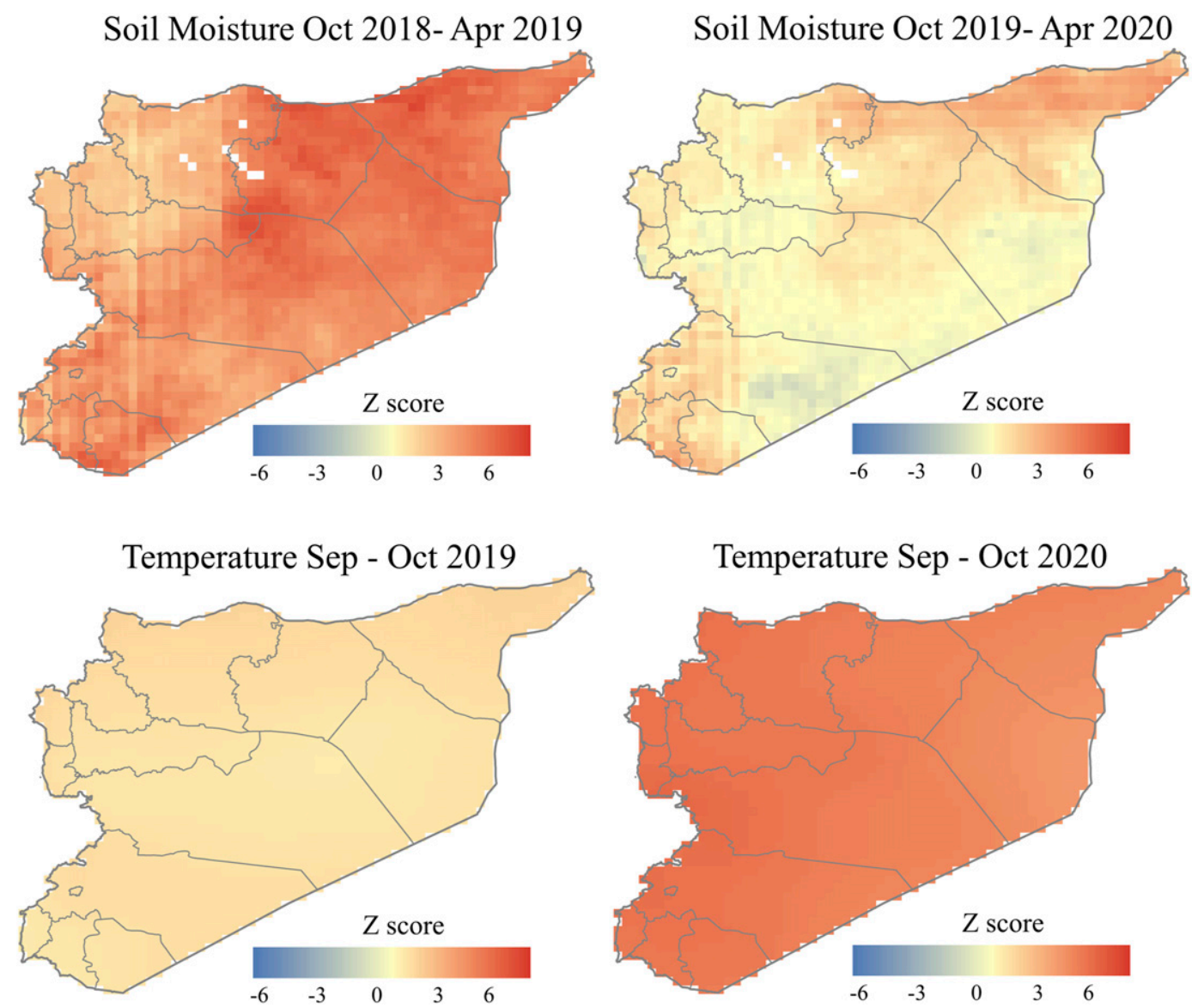

FIG. 7. Anomalies in two climate variables represented by $Z$ score: (top) anomalies in average soil moisture over the growing period, October-April; (bottom) anomalies in the maximum daily air temperature averaged over the end of the fire season, September-October.

0.50 , respectively) and cumulative FWI during the FS (MayOctober; $r=0.61)$ and the number of days with FWI above the mean during the second half of the FS (August-October; $r=$ $0.55)$. Note that October was included as a part of the FS because of abnormally high fire activity in October 2020.

Similar to BA, the SM time series showed high interannual variability (Fig. 5, right column), with the lowest amount of moisture in $2008(Z=-2.3)$ and the highest in $2019(Z=3.6)$. The surplus of moisture was even more substantial in $\mathrm{Ar}$ Raqqah and $\mathrm{Al} \mathrm{Hasakah} \mathrm{(} Z=4.2$ and 4.0; Fig. 7). In 2020, SM during the GS was $0.7 \sigma$ above the average, with again the highest excess of moisture in Ar Raqqah and Al Hasakah $(Z=$ 1.1 and 1.8 , respectively). Monthly climatology of maximum FWI showed that while the $2019 \mathrm{FS}$ as a whole had average fire weather (Fig. 6, right column), the beginning of the FS was much more prone to high fire activity in Aleppo, Hama, and Homs $(Z=1.1,1.2$, and 1.2), and in Al Hasakah September had higher than usual FWI $(Z=2.1)$. In contrast, the $2020 \mathrm{FS}$ can be characterized by very high FWI $(Z=1.7)$, the highest since 2003, specifically in May, September, and October.

Using SM during the GS preceding FS (2002-18) as an independent variable in a simple linear model, we were able to predict $61.9 \%$ of the observed BA in 2019 and $13.8 \%$ in 2020 (adjusted $R^{2}=0.53$ ). In addition, we used the fitted model to predict BA for each year of the analysis to evaluate whether the predictive power of climate varied between prewar and war periods. The results showed that, overall, our model based on SM content overpredicted BA before the beginning of the civil war $(+27.9 \%$ on average per year for $2002-10)$ and underpredicted after ( $-34.3 \%$ on average for $2011-18)$. As a percentage, the highest overprediction was detected in 2008 (the year with the lowest SM and lowest BA), while the highest underprediction was in 2020 (Fig. 8). In terms of the area, the highest underprediction was in $2019,3403 \mathrm{~km}^{2}$ was underpredicted using climate data, followed by $3048 \mathrm{~km}^{2}$ in 2020 and $997 \mathrm{~km}^{2}$ in 2015.

By splitting the time series into two periods, we found that SM was a better predictor of BA before the civil war started (adjusted $R^{2}=0.68$ as compared with 0.56 ), and while SM was a significant predictor in both models, the $p$ value varied from 0.004 (2002-10) to 0.02 (2011-18). Fitting the model for the individual FS months, we found that SM had the highest predictive power at the peak BA (June and July: adjusted $R^{2}=$ 0.52 and 0.46 , respectively) and the lowest at the end of the FS 


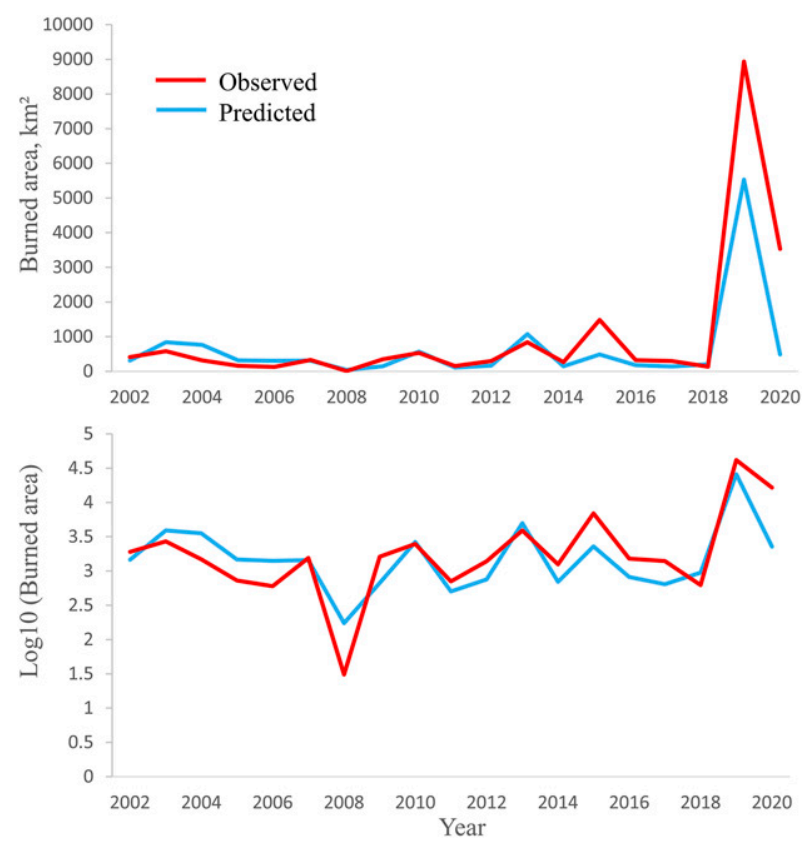

FIG. 8. Observed vs predicted burned area in Syria (2002-20). Observed values are based on the Collection-6 MODIS MCD64A1 BA product. Predicted values are based on the simple linear model that utilized soil moisture content at $0-10-\mathrm{cm}$ depth derived from FLDAS during the growing season (October-April) for 2002-18.

(August-September). Before the beginning of the civil war, SM was an even stronger BA predictor during the May-July period (adjusted $R^{2}=0.53,0.72$, and 0.78 , respectively). In contrast, FWI was not a significant predictor of BA in Syria ( $p$ value $>0.05$ ). A simple linear model based on the cumulative FWI during the FS predicted $2.9 \%$ of BA in 2019 and $16.0 \%$ in 2020 (adjusted $R^{2}=0.11$ ).

By fitting a linear regression model separately for each governorate, we were able to detect geographical differences in the predictive power of climate in Syria. The SM was the strongest predictor of BA in the northern part of the country. In fact, the prediction of $61.9 \%$ of BA in 2019 in Syria was mostly attributed to the high prediction power of SM during the GS in Al Hasakah, where our simple regression model predicted $3740.6 \mathrm{~km}^{2}$ of BA in $2019(83 \%)$ with an adjusted $R^{2}=0.42$, but only $21 \%$ in 2020 . As one moves from east to west, the percentage of 2019 BA that we could predict with SM decreased to $29.8 \%$ in Ar Raqqah and $19.27 \%$ in Aleppo, while in Hama and Homs, SM was not a significant predictor of BA. In 2020, SM was able to predict $44.3 \%$ in Ar Raqqah and $27.9 \%$ in Aleppo. On the contrary, the predictive power of maximum $T$ during the FS increased toward the west. The number of days with maximum daily $T$ above the mean during SeptemberOctober was a significant predictor of BA in Hama and Homs (adjusted $R^{2}=0.34$ and 0.15 , respectively); however, this climate metric was only able to predict $4.7 \%$ of BA in 2019 in Hama and $3.2 \%$ in Homs. Whereas, in 2020, maximum $T$ predicted $67 \%$ of BA in Hama and $19.5 \%$ in Homs.

\section{d. Neighboring countries}

In addition to Syria, changes in fire activity were also analyzed within two governorates in Iraq and six provinces in Turkey that shared a border with Syria (Fig. 9). Overall, in Nineveh and Duhok in Iraq, $388.5 \mathrm{~km}^{2}$ were affected by fire on average. This area increased by a factor of 19 in 2019 $\left(7476.3 \mathrm{~km}^{2}\right)$ and a factor of 10 in $2020\left(3815.5 \mathrm{~km}^{2}\right)$. In Turkey, fire activity in 2019 was barely above the average. The BA in six provinces of Turkey increased by a factor of 1.4 in 2019 and a factor of 1.8 in 2020 , changing from $1934.8 \mathrm{~km}^{2}$ on average to $2788.2 \mathrm{~km}^{2}$ in 2019 and $3493.5 \mathrm{~km}^{2}$ in 2020 . In fact, fire activity was substantially higher in Turkey during the 2015-17 period than in 2019 and 2020. Nonetheless, climate conditions were very similar in Syria, the south of Turkey, and the northwest part of Iraq. While both 2019 and 2020 were wetter than the average, the 2019 GS was the wettest year in the past 20 years in $\operatorname{Iraq}(Z=3.0)$ and in the south of Turkey $(Z=4.6)$.

\section{Discussion}

\section{a. Burned area versus climate}

Our analysis of BA between 2002 and 2020 based on MODIS MCD64A1 demonstrated high interannual variability and strong seasonality in fire activity in Syria. These findings were expected since resource availability is variable in arid regions, and low biomass accumulation usually limits frequent fires (Krawchuk and Moritz 2011). The observed strong positive relationship between BA and accumulated SM before the FS is consistent with the fuel-limited fire regimes in dry regions (Abatzoglou and Kolden 2013; Abatzoglou et al. 2018). According to Bradstock (2010), four processes limit fire activity: biomass production, the availability of biomass to burn, fire weather, and ignitions. In arid systems, where pronounced water deficit is a seasonal feature, ignitions and grassland productivity are the main limitations of fire (Nemani et al. 2003; Bradstock 2010). An increase in the amount of moisture available for plants can lead to high fire activity due to a boost in fuel accumulation once natural or anthropogenic ignition source is present (Archibald et al. 2009; Abatzoglou et al. 2018). Insignificant fire activity in 2008 can be explained by extreme drought, which was observed in the CHIRPS record and was documented in previous literature (Kelley et al. 2015). Similarly, an excess of rainfall during October 2012-April 2013 was followed by an above-average BA in the north part of Syria. The year 2019 experienced an abnormally high amount of rainfall; in fact, according to Red Cross (2020), heavy rains in March 2019 resulted in serious flooding in several governorates in Syria. Unsurprisingly, soil moisture available for plants was able to explain more than one-half of the unprecedented amount of burned area in 2019 within governorates with an arid or semiarid climate, and not in 2020, the year with precipitation being close to the average.

On the other hand, fire activity in the less water-limited western part of the country, which can be characterized by the Mediterranean climate, is less sensitive to moisture and more to severe ambient weather conditions during FS, similar to other Mediterranean regions (Pereira et al. 2005; Amraoui 
Cumulative fire activity 2002-2018

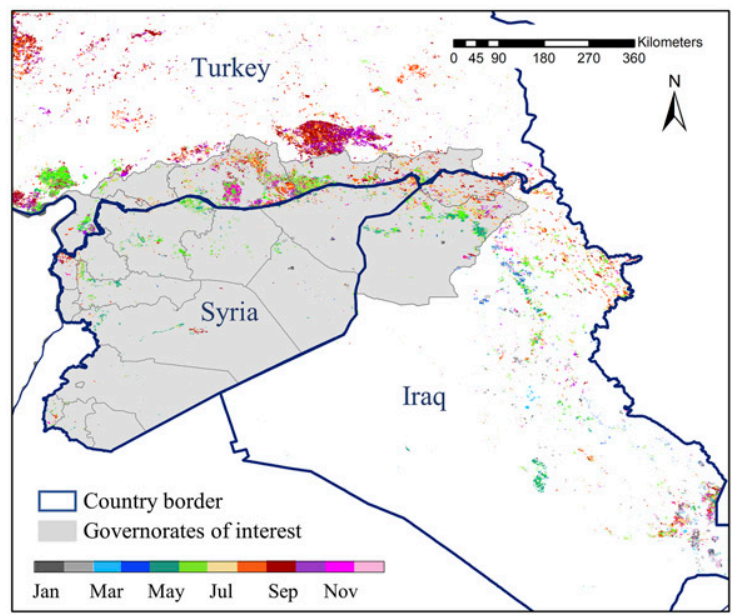

Fire activity in 2019

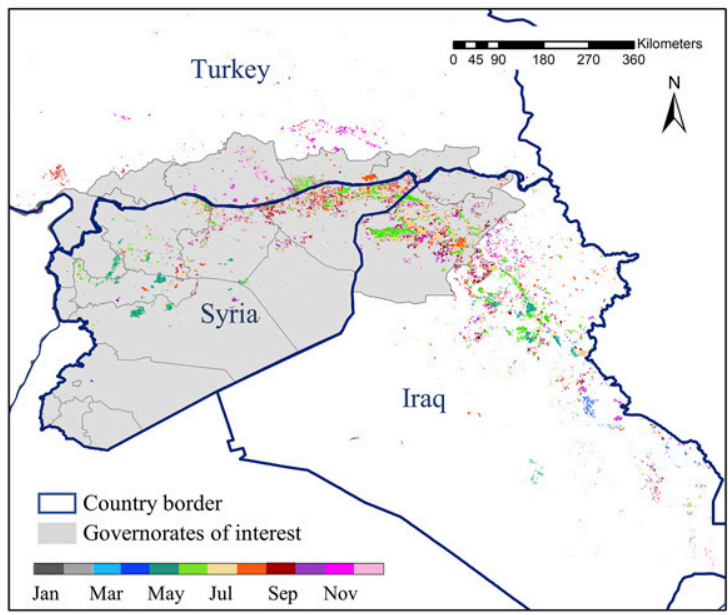

Fire activity in 2020

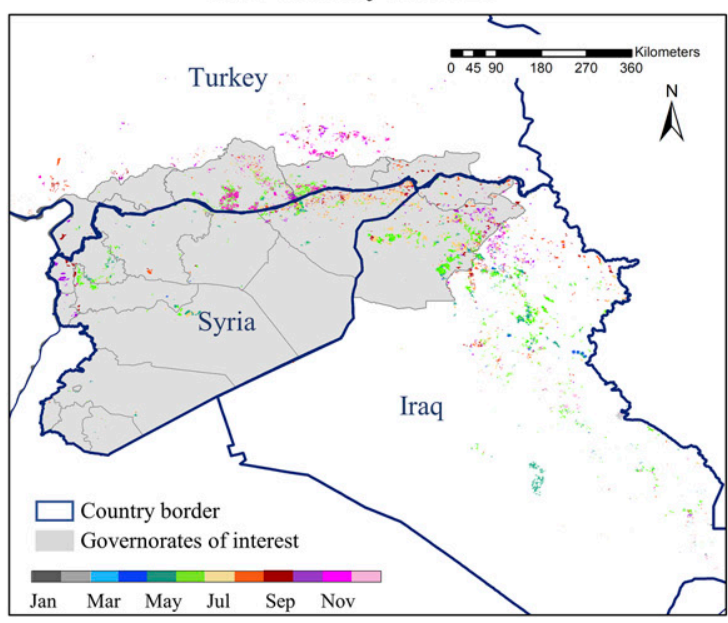

FIG. 9. Spatial distribution of fires in Syria, Iraq, and Turkey as mapped by the MODIS MCD64A1 BA product: (top) cumulative burned area from 2002 to 2018, (middle) burned area in 2019, and (bottom) burned area in 2020 . et al. 2013). Above normal temperatures and subsequently FWI that were recorded at the end of the 2020 fire season (Fig. 7), especially in the northwest part of the country, were partially responsible for the increase in fire activity in more biomass-rich ecosystems.

It might be counterintuitive that temperature-but not FWI-was found to be a significant predictor of fire activity in some governorates. Uncertainties in climate data and formulas that were used for fire danger models were likely to deteriorate the reliability of the relationships identified in this analysis. While many applications utilized model reanalysis data due to the large number of atmospheric, oceanic, and land surface quantities it provides, the reliability of its quantities varies substantially. Air temperature estimated from the reanalysis showed the lowest biases and standard deviation of errors; in the meantime, the accuracy of the precipitation and wind required for FWI calculation is substantially lower because of their high variability at a small spatial scale (Decker et al. 2012; Akinsanola et al. 2017, Beck et al. 2017). In addition, FWI was developed in Canada to reflect the behavior of forest fires and was calibrated for 16 major fuel types in Canada (Van Wagner and Pickett 1985). How close FWI is to real observations remained unclear for many parts of the globe, especially where the quality or quantity of field data about fire behavior, amount fuel, and vegetation characteristics is not sufficient (Dee et al. 2011).

Interestingly, a strong relationship between climate and fire was observed even within governorates where most fires occurred within cropland. After the beginning of the civil war, however, the relationship between burned area and climate, in particular soil moisture, although significant, was substantially reduced. While the former finding contradicts the common assumption that anthropogenic factors can effectively decouple climate and fire within human-managed land, the latter is supported by previous research that suggested a reduction of climate ability to control the fire within regions with high anthropogenic pressure, with the exception of the extreme weather events (Le Page et al. 2010; Archibald 2016; Syphard et al. 2017).

Although our analysis indicated climate as an important driver of fire activity in Syria, our simple linear model suggested that approximately one-half of the interannual variability in BA is explained by variation in SM. If the amount of moisture that plants receive during the GS and high FWI during the FS solely drove fire activity in Syria, the highest BA would be observed during 2003, the year with above-average SM and the highest cumulative FWI. The year 2003 was, in fact, the year with the highest BA before the beginning of the civil war $\left(579 \mathrm{~km}^{2}\right)$; however, when the entire time series is analyzed, 2003 comes only 5th after 2019, 2020, 2015, and 2013 $\left(8937,3542,1486\right.$, and $837 \mathrm{~km}^{2}$, respectively). The surplus of moisture was a good indicator of high BA in 2013 and 2019, while severe ambient weather conditions during the FS were able to explain some of the excess of BA in 2020, especially in the west part of the country. However, it is important to stress that more than $3000 \mathrm{~km}^{2}$ of BA (almost 8 times as much as the average annual BA) in 2019 and in 2020 was not attributed to climate according to the results of our climate analysis. 


\section{b. Anthropogenic drivers of fire activity}

Abrupt changes in spatial and especially temporal patterns of the fire activity are usually attributed to anthropogenic factors (Syphard et al. 2017). The prevalence of crop fires over natural fires in Syria can be used as an example of a positive relationship between human activity and BA in arid regions. Prior research substantiates the belief that an increase in anthropogenic activity leads to fire suppression, fuel reduction, and fragmentation; however, that was not the case in Syria. As a result of the high aridity, the productivity in Syria is very low; biomass accumulation drastically increases when land is irrigated, which creates more fuel for potential fire if the ignition is present. The anthropogenic activity also increases the number of ignitions: other than lightning strikes, human error, broken glass, or machinery fires are the main sources of accidental fire within the GS (Middleton et al. 2018), while postharvest burning to clear the fields is a standard practice typically observed between mid-July and September. Consequently, agricultural fields have not only extra fuel but also more ignition sources, which together create optimal conditions for burning.

After the beginning of the civil war, violent conflicts promoted fire activity by increasing ignitions and decreasing fire suppression. In many areas in Idlib, Ar Raqqah, Hama, and Aleppo, the front lines of military operations occurred in or around agricultural lands (Mohamed et al. 2020) — therefore creating more ignitions that led to accidental (collateral damage from bombing or firearms) and conflict-initiated deliberate fires that were the most common during the GS (Linke and Ruether 2021). At the same time, conflicts negatively affected the fire response services (Middleton et al. 2018). All of the above can explain not only changes in the extent of BA but also its seasonality. The amount of BA detected in May more than doubled, which can have significant economic implications and impacts on food security since most of the fires were observed within cropland, and the main crops, wheat and barley, are not harvested in Syria until June. In addition, since 2011 the length of the FS started to extend. More fires were ignited in September and October; fire activity that late in the season is not typical for Syria.

\section{c. The interplay between fire, conflict, climate, and vegetation}

Our study demonstrated that the number of violent conflicts alone cannot explain the abnormally high fire activity in 2019 and 2020. More area was affected by fire in 2019 alone than during the previous 17 years combined, while the analysis of violent conflicts demonstrated a decrease in conflict intensity after 2016, making 2019 and especially 2020 much more stable when compared with the beginning of the civil war. Therefore, some might argue that if conflicts were responsible for the drastic increase in fire activity, the highest BA would be observed in 2012 and not in 2019. Indeed, ignitions cannot guarantee fire; fuel and fire favorable weather are also required to ease ignition and propagation (Bradstock 2010). As discussed earlier, unprecedentedly high rainfall during winter-spring 2019 undoubtedly played a major role in the drastic increase of fire activity. However, if excess rainfall were the primary driver of fire in the north part of Syria, a similar drastic increase in BA would be observed within its neighbors Iraq and especially Turkey that received a comparably high amount of rainfall in 2019. However, our analysis demonstrated that only Iraq, where, like Syria, the Islamic State controls a large proportion of cropland (Eklund et al. 2017; Gibson 2019; Humud and Blanchard 2020), was strongly affected by fire in 2019.

Moreover, Schon et al. (2021) attributed a sudden increase in fire activity in Syria in 2019 to agricultural renewal from end-of-conflict stabilization since most subdistricts outside Kurdish-controlled territory were not affected by the fire. However, the analysis of fire activity within different landcover types and during 2020 demonstrated that the situation in Syria might not be as straightforward. While 19 times as much BA was detected within cropland in 2019, the change within natural land was even more drastic; 40 times as much BA was detected outside of agricultural land. In 2020, fire activity moved to the west, away from wheat and barley's major production to government- or opposition-controlled territory. According to FAO (2020), between August and September, more than $220 \mathrm{~km}^{2}$ of forests and orchards were burnt in Homs, Hama, Latakia, and Tartūs. The prevalence of fire despite the overall improvement of Syria's relative stability might be explained by changes in conflict events within individual governorates. Based on ACLED, conflict intensity was substantially reduced in the south of Syria, within governorates that hardly experience fire activity due to very arid climate and therefore very low fuel accumulation. On the contrary, an increase in the number of conflicts was detected in $\mathrm{Al}$ Hasakah and $\mathrm{Ar}$ Raqqah, specifically within cropland, and in the northwest part of Syria, where security situation remained volatile at the end of 2020 (WFP 2020b). Therefore, conflict intensity facilitated fire activity in governorates with either arid climate if sufficient amount of biomass was present due to increase in rainfall (northeast), or in non-water-limited ecosystems once weather conditions were suitable for fire ignition and propagation (northwest).

Fire-favorable weather conditions, poor emergency response due to the war, and maliciously started fires by the Islamic State, progovernment militias, or opposition rebels (BBC 2019b; Enab Baladi 2019; Sly 2019) are not a comprehensive list of potential drivers of the current high amount of BA in Syria. According to Schon et al. (2019), low-quality fuel and a lack of skilled agricultural labor due to the prolonged conflict and mass population displacement could have also contributed to the unusual fire activity. In arid regions, where severe ambient weather conditions are present during the majority of the year, one spark from bad fuel or a lit cigarette during the harvest period can start a fire that spreads rapidly and affects vast areas, especially in the absence of fire response services that was observed in the 2019 and 2020 fire seasons. In addition, because of an unstable economy, a lack of fertilizer, low crop prices, and high coal prices, people encroach on forest territories in the west (Wilks 2020). The locals exploit forest fires to expand the area of farming or pasture, for logging, and for charcoal trading (Shehadah and Ziadeh 2020). Between 2010 and 2018, Syria has lost one-quarter of its forest 
(Berdikeeva 2019), specifically $70 \%$ of the forest in Idlib (Action on Armed Violence 2020b).

Ultimately, while our analysis of BA is the first step toward the improvement of our understanding of the mechanism behind the extraordinary fire activity in Syria, it demonstrated the complexity of the relationship between fire, climate, conflict, economy, migration, and land use. Future research is needed to analyze the nature of the violent conflicts and to evaluate the impact of fires on food security, agriculture, livelihood, and biodiversity. Increased pressure on scarce natural resources, water, pastures, and forests, together with an increase of soil erosion and consequently degradation, was already documented in Syria (Abdo 2018; Almohamad 2020; Mohamed et al. 2020; Mohammed et al. 2020b). Therefore, special attention should be paid to the agricultural sector and fire management, promoting sustainable agricultural and environmental policies to protect natural resources and conserve fragile soil in Syria (Mohamed et al. 2020).

Acknowledgments. This research was supported in part by National Aeronautics and Space Administration Grant 80NSSC18K0739. We thank Philip Frost for valuable discussion and critical reading of the paper.

Data availability statement. Data analyzed in this study were a reanalysis of existing data, which are openly available at locations cited in the reference section.

\section{REFERENCES}

Abatzoglou, J. T., and C. A. Kolden, 2013: Relationships between climate and macroscale area burned in the western United States. Int. J. Wildland Fire, 22, 1003, https://doi.org/10.1071/ WF13019.

, A. P. Williams, L. Boschetti, M. Zubkova, and C. A. Kolden, 2018: Global patterns of interannual climate-fire relationships. Global Change Biol., 24, 5164-5175, https://doi.org/ 10.1111/gcb.14405.

Abdo, H. G., 2018: Impacts of war in Syria on vegetation dynamics and erosion risks in Safita area, Tartous, Syria. Reg. Environ. Change, 18, 1707-1719, https://doi.org/10.1007/s10113-0181280-3.

Akinsanola, A. A., K. O. Ogunjobi, V. O. Ajayi, E. A. Adefisan, J. A. Omotosho, and S. Sanogo, 2017: Comparison of five gridded precipitation products at climatological scales over West Africa. Meteor. Atmos. Phys., 129, 669-689, https:// doi.org/10.1007/s00703-016-0493-6.

Almohamad, H., 2020: Impact of land cover change due to armed conflicts on soil erosion in the basin of the northern Al-Kabeer River in Syria using the RUSLE model. Water, 12, 3323, https://doi.org/10.3390/w12123323.

Almukhtar, S., 2016: Life under the Islamic State: Fines, taxes and punishments. New York Times, accessed 18 May 2021, https:// www.nytimes.com/interactive/2016/05/26/world/middleeast/ isis-taxes-fines-revenue.html.

Amnesty International, 2020: "Nowhere is safe for us" unlawful attacks and mass displacement in northwest Syria. Accessed 18 May 2021. https://reliefweb.int/sites/reliefweb.int/files/ resources/MDE2420892020ENGLISH.PDF.

Amraoui, M., M. L. R. Liberato, T. J. Calado, C. C. DaCamara, L. P. Coelho, R. M. Trigo, and C. M. Gouveia, 2013: Fire activity over Mediterranean Europe based on information from Meteosat-8. For. Ecol. Manage, 294, 62-75, https:// doi.org/10.1016/j.foreco.2012.08.032.

Action on Armed Violence, 2020a: Car bomb kills 19 civilians in northern Syria. Accessed 18 May 2021, https://reliefweb.int/ report/syrian-arab-republic/car-bomb-kills-19-civilians-northern-syria.

, 2020b: The broken land: The environmental consequences of explosive weapon use. AOAV, 31 pp., accessed 4 April 2021, https://reliefweb.int/sites/reliefweb.int/files/resources/TheBroken-Land-v4.pdf.

Archibald, S., 2016: Managing the human component of fire regimes: Lessons from Africa. Philos. Trans. Roy. Soc., B371, 20150346, https://doi.org/10.1098/rstb.2015.0346.

- D. P. Roy, B. W. V. Wilgen, and R. J. Scholes, 2009: What limits fire? An examination of drivers of burnt area in southern Africa. Global Change Biol., 15, 613-630, https://doi.org/ 10.1111/j.1365-2486.2008.01754.x.

Asharq Al-Awsat, 2019: Crop fires ruin Iraqi, Syrian harvests. Accessed 4 April 2021, https://english.aawsat.com/home/ article/1746196/crop-fires-ruin-iraqi-syrian-harvests.

Assistance Coordination Unit, 2019: Crops fires in north west and north east of Syria. Information Management Unit, $7 \mathrm{pp}$., https://reliefweb.int/sites/reliefweb.int/files/resources/IMU_ Crops_Fires_Eng_June_2019.pdf.

Balch, J. K., B. A. Bradley, J. T. Abatzoglou, R. C. Nagy, E. J. Fusco, and A. L. Mahood, 2017: Human-started wildfires expand the fire niche across the United States. Proc. Natl. Acad. Sci. USA, 114, 2946-2951, https://doi.org/10.1073/ pnas.1617394114.

Barbero, R., J. T. Abatzoglou, N. K. Larkin, C. A. Kolden, and B. Stocks, 2015: Climate change presents increased potential for very large fires in the contiguous United States. Int. J. Wildland Fire, 24, 892-899, https://doi.org/10.1071/ WF15083.

BBC, 2019a: Syria profile-Timeline. BBC News, accessed 4 April 2021, https://www.bbc.com/news/world-middle-east14703995.

- 2019b: Syrian military 'burning crops in rebel-held north.' BBC News, accessed 4 April 2021, https://www.bbc.com/news/ world-middle-east-48444596.

Beck, H. E., and Coauthors, 2017: Global-scale evaluation of 22 precipitation datasets using gauge observations and hydrological modeling. Hydrol. Earth Syst. Sci., 21, 6201-6217, https://doi.org/10.5194/hess-21-6201-2017.

Bedia, J., N. Golding, A. Casanueva, M. Iturbide, C. Buontempo, and J. M. Gutiérrez, 2018: Seasonal predictions of Fire Weather Index: Paving the way for their operational applicability in Mediterranean Europe. Climate Serv., 9, 101-110, https://doi.org/10.1016/j.cliser.2017.04.001.

Berdikeeva, S., 2019: Woodlands of the Middle East: Missing the forest for the trees. Inside Arabia, accessed 4 April 2021, https://insidearabia.com/woodlands-of-the-middle-east-missingthe-forest-for-the-trees/.

Bird, R. B., B. F. Codding, P. G. Kauhanen, and D. W. Bird, 2012: Aboriginal hunting buffers climate-driven fire-size variability in Australia's spinifex grasslands. Proc. Natl. Acad. Sci. USA, 109, 10 287-10292, https://doi.org/10.1073/pnas.1204585109.

Bowman, D. M. J. S., and Coauthors, 2011: The human dimension of fire regimes on Earth. J. Biogeogr., 38, 2223-2236, https:// doi.org/10.1111/j.1365-2699.2011.02595.x.

Bradstock, R. A., 2010: A biogeographic model of fire regimes in Australia: Current and future implications. Global Ecol. 
Biogeogr., 19, 145-158, https://doi.org/10.1111/j.1466-8238. 2009.00512.x

Council on Foreign Relations, 2021: Civil War in Syria. Global Conflict Tracker, accessed 18 May 2021, https://www.cfr.org/ global-conflict-tracker/conflict/civil-war-syria.

Daniau, A.-L., and Coauthors, 2012: Predictability of biomass burning in response to climate changes. Global Biogeochem. Cycles, 26, GB4007, https://doi.org/10.1029/ 2011 GB004249.

Decker, M., M. Brunke, Z. Wang, K. Sakaguchi, X. Zeng, and M. Bosilovich, 2012: Evaluation of the reanalysis products from GSFC, NCEP, and ECMWF using flux tower observations. J. Climate, 25, 1916-1944, https://doi.org/10.1175/JCLID-11-00004.1.

Dee, D. P., and Coauthors, 2011: The ERA-Interim reanalysis: Configuration and performance of the data assimilation system. Quart. J. Roy. Meteor. Soc., 137, 553-597, https://doi.org/ 10.1002/qj.828.

Eklund, L., M. Degerald, M. Brandt, A. V. Prishchepov, and P. Pilesjö, 2017: How conflict affects land use: Agricultural activity in areas seized by the Islamic State. Environ. Res. Lett., 12, 054004, https://doi.org/10.1088/1748-9326/aa673a.

Enab Baladi, 2019: Agricultural crops weaponized by Syria's warring parties. Accessed 4 April 2021, https://english.enabbaladi.net/ archives/2019/06/agricultural-crops-weaponized-by-syriaswarring-parties/.

Encyclopaedia Britannica Online, 2020: Syrian Civil War. Accessed 18 May 2021, https://www.britannica.com/event/ Syrian-Civil-War.

ESA, 2017: Land Cover CCI: Product user guide, version 2. ESA Tech. Rep. 105 pp., maps.elie.ucl.ac.be/CCI/viewer/download/ ESACCI-LC-Ph2-PUGv2_2.0.pdf.

FAO, 2019: Syria crisis-Situation report September 2019. United Nations Doc., 2 pp., http://www.fao.org/3/ca7646en/ ca7646en.pdf.

— 2020: GIEWS country brief: Syrian Arab Republic. United Nations Doc., 3 pp., https://reliefweb.int/sites/reliefweb.int/ files/resources/SYR_14.pdf.

Flannigan, M., B. Stocks, M. Turetsky, and M. Wotton, 2009: Impacts of climate change on fire activity and fire management in the circumboreal forest. Global Change Biol., 15, 549-560, https://doi.org/10.1111/j.1365-2486.2008.01660.x.

Gibson, G., 2019: Effects of the Islamic State of Iraq and Syria on cropland area. J. Food Secur., 7, 20-27.

Giglio, L., L. Boschetti, D. P. Roy, M. L. Humber, and C. O. Justice, 2018: The Collection 6 MODIS burned area mapping algorithm and product. Remote Sens. Environ., 217, 72-85, https://doi.org/10.1016/j.rse.2018.08.005.

Gorsevski, V., E. Kasischke, J. Dempewolf, T. Loboda, and F. Grossmann, 2012: Analysis of the impacts of armed conflict on the Eastern Afromontane forest region on the South Sudan-Uganda border using multitemporal Landsat imagery. Remote Sens. Environ., 118, 10-20, https://doi.org/10.1016/ j.rse.2011.10.023.

— M. Geores, and E. Kasischke, 2013: Human dimensions of land use and land cover change related to civil unrest in the Imatong Mountains of South Sudan. Appl. Geogr., 38, 64-75, https://doi.org/10.1016/j.apgeog.2012.11.019.

Group on Earth Observations Global Agricultural Monitoring, 2021: Syrian Arab Republic: Conflict and food insecurity. GEOGLAM Conflict Rep., 16 pp., https://reliefweb.int/sites/ reliefweb.int/files/resources/Conflict_Report_20210101_ Syrian_Arab_Republic.pdf.
Hassan, F., and R. Nordland, 2018: Battered ISIS keeps grip on last piece of territory for over a year. New York Times, accessed 18 May 2021, https://www.nytimes.com/2018/12/09/world/ middleeast/isis-territory-syria-iraq.html.

Hersbach, H., and Coauthors, 2020: The ERA5 global reanalysis. Quart. J. Roy. Meteor. Soc., 146, 1999-2049, https://doi.org/ 10.1002/qj.3803.

Higgins, S. I., W. J. Bond, and W. S. W. Trollope, 2000: Fire, resprouting and variability: A recipe for grass-tree coexistence in savanna. J. Ecol., 88, 213-229, https://doi.org/10.1046/j.13652745.2000.00435.x.

Humud, C. E., and C. M. Blanchard, 2020: Armed conflict in Syria: Overview and U.S. response. Congressional Research Service Rep., 53 pp., https://crsreports.congress.gov/product/pdf/ download/RL/RL33487/RL33487.pdf/.

ICEWS, 2016: ICEWS coded event data read me. National Bureau of Economic Research Doc., 3 pp., http://data.nber.org/ens/ feldstein/NBER_Sources/ENS\%20Conference\%20Sources/ 2016/Predicting\%20Conflict\%20Via\%20Machine\%20Learning/ ICEWS\%20(Lockheed\%20Martin)/Coded\%20Event\%20Data/ ICEWS\%20Coded\%20Event\%20Data\%20Read\%20Me.pdf.

Kelley, C. P., S. Mohtadi, M. A. Cane, R. Seager, and Y. Kushnir, 2015: Climate change in the Fertile Crescent and implications of the recent Syrian drought. Proc. Natl. Acad. Sci. USA, 112, 3241-3246, https://doi.org/10.1073/pnas.1421533112.

Koren, O., and B. E. Bagozzi, 2017: Living off the land: The connection between cropland, food security, and violence against civilians. J. Peace Res., 54, 351-364, https://doi.org/10.1177/ 0022343316684543.

Krawchuk, M. A., and M. A. Moritz, 2011: Constraints on global fire activity vary across a resource gradient. Ecology, 92, 121132, https://doi.org/10.1890/09-1843.1.

Kreyszig, E., 1979: Advanced Engineering Mathematics. 4th ed. John Wiley and Sons, $880 \mathrm{pp}$.

Le Page, Y., D. Oom, J. M. N. Silva, P. Jönsson, and J. M. C. Pereira, 2010: Seasonality of vegetation fires as modified by human action: Observing the deviation from eco-climatic fire regimes. Global Ecol. Biogeogr., 19, 575-588, https://doi.org/ 10.1111/j.1466-8238.2010.00525.x.

Linke, A. M., and B. Ruether, 2021: Weather, wheat, and war: Security implications of climate variability for conflict in Syria. J. Peace Res., 58, 114-131, https://doi.org/10.1177/ 0022343320973070.

Littell, J. S., D. McKenzie, D. L. Peterson, and A. L. Westerling, 2009: Climate and wildfire area burned in western U.S. ecoprovinces, 1916-2003. Ecol. Appl., 19, 1003-1021, https:// doi.org/10.1890/07-1183.1.

Marlon, J. R., and Coauthors, 2008: Climate and human influences on global biomass burning over the past two millennia. Nat. Geosci., 1, 697-702, https://doi.org/10.1038/ngeo313.

Martínez-Fernández, J., E. Chuvieco, and N. Koutsias, 2013: Modelling long-term fire occurrence factors in Spain by accounting for local variations with geographically weighted regression. Nat. Hazards Earth Syst. Sci., 13, 311-327, https:// doi.org/10.5194/nhess-13-311-2013.

McNally, A., and Coauthors, 2017: A land data assimilation system for sub-Saharan Africa food and water security applications. Sci. Data, 4, 170012, https://doi.org/10.1038/sdata.2017.12.

Middleton, S., L. Öhman, P. Dorsher, A. Al Kaddour, A. Folan, and D. Humphries, 2018: Resilience through humanitarian assistance: Agriculture in the Syria conflict. Global Communities Doc., 36 pp., https://reliefweb.int/sites/reliefweb.int/files/resources/ syria-publication-2018-web.pdf. 
Mohamed, M. A., J. Anders, and C. Schneider, 2020: Monitoring of changes in land use/land cover in Syria from 2010 to 2018 using multitemporal Landsat imagery and GIS. Land, 9, 226, https:// doi.org/10.3390/land9070226.

Mohammed, S., and Coauthors, 2020b: Estimating human impacts on soil erosion considering different hillslope inclinations and land uses in the coastal region of Syria. Water, 12, 2786, https:// doi.org/10.3390/w12102786.

— A. Alkerdi, J. Nagy, and E. Harsányi, 2020a: Syrian crisis repercussions on the agricultural sector: Case study of wheat, cotton and olives. Reg. Sci. Policy Pract., 12, 519-537, https:// doi.org/10.1111/rsp3.12222.

Moreira, F., F. C. Rego, and P. G. Ferreira, 2001: Temporal (19581995) pattern of change in a cultural landscape of northwestern Portugal: Implications for fire occurrence. Landscape Ecol., 16, 557-567, https://doi.org/10.1023/A:1013130528470.

Nemani, R. R., C. D. Keeling, H. Hashimoto, W. M. Jolly, S. C. Piper, C. J. Tucker, R. B. Myneni, and S. W. Running, 2003: Climate-driven increases in global terrestrial net primary production from 1982 to 1999 . Science, 300, 1560-1563, https:// doi.org/10.1126/science.1082750.

Parisien, M.-A., and M. A. Moritz, 2009: Environmental controls on the distribution of wildfire at multiple spatial scales. Ecol. Monogr., 79, 127-154, https://doi.org/10.1890/07-1289.1.

Parks, S. A., C. Miller, J. T. Abatzoglou, L. M. Holsinger, M.-A., Parisien, and S. Z. Dobrowski, 2016: How will climate change affect wildland fire severity in the western US? Environ. Res. Lett., 11, 035002, https://doi.org/10.1088/17489326/11/3/035002.

Pausas, J. G., 2004: Changes in fire and climate in the eastern Iberian Peninsula (Mediterranean Basin). Climatic Change, 63, 337-350, https://doi.org/10.1023/ B:CLIM.0000018508.94901.9c.

— western Mediterranean Basin: From fuel-limited to droughtdriven fire regime. Climatic Change, 110, 215-226, https:// doi.org/10.1007/s10584-011-0060-6.

Pereira, M. G., R. M. Trigo, C. C. da Camara, J. M. C. Pereira, and S. M. Leite, 2005: Synoptic patterns associated with large summer forest fires in Portugal. Agric. For. Meteor., 129, 1125, https://doi.org/10.1016/j.agrformet.2004.12.007.

Raleigh, C., A. Linke, H. Hegre, and J. Karlsen, 2010: Introducing ACLED-Armed Conflict Location and Event Data. J. Peace Res., 47, 651-660, https://doi.org/10.1177/0022343310378914.

Red Cross, 2020: Emergency appeal final report, Syria: Floods. IFRC Doc., 25 pp., accessed 13 May 2021, https://reliefweb.int/ sites/reliefweb.int/files/resources/MDRSY004efr_0.pdf.

Rubel, F., and M. Kottek, 2010: Observed and projected climate shifts 1901-2100 depicted by world maps of the KöppenGeiger climate classification. Meteor. Z., 19, 135-141, https:// doi.org/10.1127/0941-2948/2010/0430.

Schon, J., R. D. Field, and M. J. Puma, 2019: How fires threaten Syria's security. New Security Beat, accessed 7 April 2021, https://www.newsecuritybeat.org/2019/10/fires-threaten-syriassecurity/\#: :text=Fires\%20are\%20proliferating.,by $\% 20$ the $\%$ 20nongovernmental\%20organization \%2C\%20REACH.

—, K. Mezuman, A. Heslin, R. D. Field, and M. J. Puma, 2021: How fire patterns reveal uneven stabilization at the end of conflict: Examining Syria's unusual fire year in 2019. Environ. Res. Lett., 16, 044046, https://doi.org/10.1088/1748-9326/abe327.

Selby, J., O. S. Dahi, C. Frohlich, and M. Hulme, 2017: Climate change and the Syrian civil war revisited. Polit. Geogr., 60, 232-244, https://doi.org/10.1016/j.polgeo.2017.05.007.
Shehadah, H., and A. Ziadeh, 2020: Negligence and corruption have set Syria's forests ablaze. Enab Baladi, accessed 4 April 2021, https://english.enabbaladi.net/archives/2020/ 09/negligence-and-corruption-have-set-syrias-forests-ablaze/ \#ixzz6ovpps7Uu.

Sly, L., 2019: Mystery crop fires scorch thousands of acres in Syria and Iraq-And ISIS claims responsibility. Washington Post, accessed 4 April 2021, https://www.washingtonpost.com/world/ mystery-crop-fires-scorch-thousands-of-acres-in-syria-and-iraq-and-isis-claims-responsibility/2019/06/07/8507eb00-87a1-11e99d73-e2ba6bbf1b9b_story.html.

Syrian Observatory for Human Rights, 2020: Syrian revolution nine years on: 586,100 persons killed and millions of Syrians displaced and injured. Accessed 18 May 2021, https://www. syriahr.com/en/157193.

Strand, H., S. A. Rustad, H. Urdal, and H. M. Nygård, 2019: Trends in armed conflict, 1946-2018. Conflict Trends, No. 3, Peace Research Institute Oslo, https://www.prio.org/utility/DownloadFile.ashx? id $=1858 \&$ type $=$ publicationfile.

Syphard, A. D., V. C. Radeloff, J. E. Keeley, T. J. Hawbaker, M. K. Clayton, S. I. Stewart, and R. B. Hammer, 2007: Human Influence on California fire regimes. Ecol. Appl., 17, 13881402, https://doi.org/10.1890/06-1128.1.

_ J. E. Keeley, A. H. Pfaff, and K. Ferschweiler, 2017: Human presence diminishes the importance of climate in driving fire activity across the United States. Proc. Natl. Acad. Sci. USA, 114, 13 750-13 755, https://doi.org/10.1073/pnas.1713885114.

Tothova, M., and Coauthors, 2019: FAO/WFP Crop and Food Security Assessment Mission to the Syrian Arab Republic. FAO World Food Programme Rep., 90 pp., http://www. fao.org/3/ca5934EN/ca5934en.pdf.

United Nations, 2019: World population prospects 2019. UN Department of Economic and Social Affairs Population Division, accessed 4 April 2021, https://population.un.org/wpp/.

United Nations Security Council, 2020: With deteriorating economy, record-level food insecurity, Syria's people at 'a breaking point', chief tells Security Council. United Nations, accessed 4 April 2021, https://www.un.org/press/en/2020/sc14231.doc.htm.

Van Wagner, C. E., and T. L. Pickett, 1985: Equations and FORTRAN program for the Canadian forest fire weather index system. Canadian Forest Service Forestry Tech. Rep. 33, 18 pp., https://d1ied5g1xfgpx8.cloudfront.net/pdfs/19973.pdf.

Viedma, O., N. Moity, and J. M. Moreno, 2015: Changes in landscape fire-hazard during the second half of the 20th century: Agriculture abandonment and the changing role of driving factors. Agric. Ecosyst. Environ., 207, 126-140, https://doi.org/ 10.1016/j.agee.2015.04.011.

Vitolo, C., F. Di Giuseppe, C. Barnard, R. Coughlan, J. SanMiguel-Ayanz, G. Libertá, and B. Krzeminski, 2020: ERA5based global meteorological wildfire danger maps. Sci. Data, 7 , 216, https://doi.org/10.1038/s41597-020-0554-z.

Walker, S., and K. Shaheen, 2016: Syria ceasefire appears to hold after rivals sign Russia-backed deal. Guardian, accessed 18 May 2021, https://www.theguardian.com/world/2016/dec/ 29/syrian-government-and-rebels-have-signed-ceasefire-agreementsays-putin.

WFP, 2020a: Syria fire incidents analysis of fires outbreak across Syria. United Nations Doc., 6 pp., https://reliefweb.int/sites/ reliefweb.int/files/resources/WFP-0000119993.pdf.

_ 2020b: WFP Syria country brief: November 2020. United Nations Doc., 2 pp., https://reliefweb.int/sites/reliefweb.int/ files/resources $/ 2020 \% 2011 \% 20$ Syria \% 20Country\%20Brief \% 20-\%20November\%202020.pdf. 
_ 2021: Syria situation report \#1: January 2021. United Nations Doc., 3 pp., https://reliefweb.int/sites/reliefweb.int/files/resources/ 2021\%2001\%20WFP\%20Syria\%20External\%20Situation \% 20Report\%2001\%20-\%20January.pdf.

Wilks, A., 2020: Bushfires devastate northwest Syria's Latakia and Hama. National News, accessed 4 April 2021, https://www. thenationalnews.com/world/mena/bushfires-devastate-northwest-syria-s-latakia-and-hama-1.1075299.

Wotton, B. M., 2009: Interpreting and using outputs from the Canadian Forest Fire Danger Rating System in research ap- plications. Environ. Ecol. Stat., 16, 107-131, https://doi.org/ 10.1007/s10651-007-0084-2.

Yacoubian, M., 2021: Syria timeline: Since the uprising against Assad. U.S. Institute of Peace, accessed 18 May 2021, https://www.usip.org/syria-timeline-uprising-againstassad.

Zubkova, M., L. Boschetti, J. T. Abatzoglou, and L. Giglio, 2019: Changes in fire activity in Africa from 2002 to 2016 and their potential drivers. Geophys. Res. Lett., 46, 7643-7653, https:// doi.org/10.1029/2019GL083469. 